\title{
The Invisible Woman? Reflections on the Figure of Barbara in Grillparzer's Der arme Spielmann
}

\section{Martin Sutton}

In his introduction to a recent collection of articles on Der arme Spielmann the editor, Clifford Albrecht Bernd, points out that this story by Grillparzer has "exercised a particular fascination on English and American readers"1 and that it has received what might appear to be an undue amount of attention from English and American critics when one considers the comparative neglect which the story suffered for so long in Europe after its first publication in 1847. Not only has Der arme Spielmann been the subject of many an illuminating analysis and commentary by English-speaking critics but also - and surprisingly, especially for Continental critics - it has often been claimed by the former to be the greatest of all of Grillparzer's works, of a higher literary standard than any of his dramas. ${ }^{2}$

This claim may seem all the more surprising in the light of the fact that Grillparzer himself did not rate his prose works particularly highly in comparison with his verse dramas. ${ }^{3}$ Nevertheless, one of Grillparzer's own diary entries should alert us to the dangers of dismissing the story as a literary lightweight:

Ich erinnerte mich dieser Rezension [von Goethes Geschwistern] bei Gelegenheit einer andern von einem ähnlichen - Kritiker über meine Erzählung: ein alter Spielmann. Es geht eben mit der Betrachtung von Kunstwerken wie mit der Beschauung von Naturgegenständen. Während der stumpfe Sinn des gewöhnlichen Hinschlenderers beim Anblick eines Baumes eben nichts bemerkt, als daß er grün sei, sieht das scharfe, wohl gar kunstgeübte Auge eine solche Welt von Abstufungen der Farbe und des Lichts, daß er stundenlange stehen und immer wieder den Baum betrachten kann, ja, wenn er Maler ist und eine Nachbildung versuchen will, gerät er in Verzweiflung auf der Palette jene Farben zu finden, die der andere mit der allgemeinen Bezeichnung: grün so schnell abgefertigt hat. Es soll hier nicht eine Parallele zwischen jener anspruchslosen Erzählung und einem Meisterwerke Goethes gezogen, sondern nur darauf aufmerksam gemacht werden, welch ungeheurer Unterschied bei den einfachsten Gegenständen zwischen einem sinnigen Betrachter sei und einem Dummkopf. ${ }^{4}$

1. C. Bernd (Ed.), Grillparzer's Der arme Spielmann. New Directions in Criticism. Columbia 1988, p. 5.

2. Ibid, pp. 4-5.

3. See B. von Wiese, Die deutsche Novelle von Goethe bis Kafka. Vol. 1. Düsseldorf 1964, p. 134, and W. Silz, Realism and Reality. Studies in the German Novelle of Poetic Realism. Chapel Hill 1954. Chap. 6, pp. 67-78, esp. p. 67.

4. Entry no. 3979 "nach dem 9. November" (1847). In: Franz Grillparzer, 
Grillparzer may seem to disparage his story in the phrase "einer anspruchslosen Erzählung", but this should be read more as an expression of modesty than as a well-considered critical evaluation. During the last forty to fifty years critics have adopted a much more patient and respectful approach than the unnamed reviewer mentioned by Grillparzer and have rightly revealed the story to be indeed "eine Welt von Abstufungen der Farbe und des Lichts". It repays constant rereading. No sooner does one believe that one has fully understood and exhausted its many nuances than yet more subtle gradations and layers of meaning reveal themselves.

The titular figure, the poor musician Jakob, and his life-story have naturally been the traditional focus of previous commentaries. More recently - within the last twenty years, that is - the story's unnamed narrator has been seen to be an equally important character in the story and his personality has been the subject of some intriguing investigation and analysis. ${ }^{5}$ The third figure in the story though, its heroine Barbara, is the one who, with the exception of one or two brief summations of her character, ${ }^{6}$ has been most ignored and, as a consequence, most misunderstood. Unjustly so, I believe. After all, the story reaches its poignant conclusion at the moment when the narrator's eyes focus on hers, and the last image we as readers are privy to is that of Barbara's face streaming with uncontrollable tears. How little justice is done to the nature and intensity of Barbara's emotion here by three different comments from three different critics:

Whether one can say that Barbara 'loves' Jakob in the commonly accepted sense seems dubious. That she reveres him is beyond doubt. ${ }^{7}$

Sämtliche Werke. Ausgewählte Briefe, Gespräche, Berichte. Ed. by Peter Frank and Karl Pörnbacher. 4 volumes. Munich 1960-65. $(=G W)$. Here: $G W$ Vol. 4, p. 713.

5. Notably by H. Politzer, Franz Grillparzers "Der arme Spielmann". Stuttgart 1967 and Franz Grillparzer, oder, Das abgründige Biedermeier. Vienna 1972, M. Swales, "'As ashamed of the story as if I had written it myself...:Reflections on the Narrator in Der arme Spielmann." in: Bernd, op. cit., pp. 66-78, and J. Ellis, Narration in the German Novelle. Theory and Interpretation. London 1974. Chap. 5, pp. 113-135. Adapted version of this chapter also in: Bernd, op. cit., pp. $27-44$.

6. E.g. Silz's penetrating but undeveloped observations, op. cit., pp. 71, 77f. Also Barbara Lindsey, "Music in Der arme Spielmann with Special Consideration to the Elements of the Sacred and Profane" (in Bernd, op cit., pp. 273-286), who is one of the few to notice that "Jakob sees in her [Barbara] something no one before him has seen" (p. 279).

7. Robert M. Browning, "Language and the Fall from Grace in Grillparzer's 
Die "Grieslers"-Tochter ist [...] zu der Gestalt einer Mutter [erwachsen], die über die Unmöglichkeit des Menschenkindes Jakob, der Menschenkinder überhaupt ihre Tränen ausschüttet. ${ }^{8}$

\section{Her tears are tears of regret and of old guilt. ${ }^{9}$}

It is my contention that Barbara's tears here at the very end of the story are tears of genuine love ${ }^{10}$ and of genuine sorrow, sorrow that springs from her realisation of the impossibility of this love. It is also my contention that she is the one truly tragic figure in the story, far more so than Jakob, who dies, as one might expect a tragic hero to do, but who dies in ignorance - blissful ignorance one could say - of Barbara's true feelings for him. Only Barbara herself knows the real nature of her tragedy and this knowledge makes her into an archetypal tragic heroine: one who must choose and act, one who as the consequence of her choice and actions must suffer, but one also who knows and feels to the full human extent her own tragic plight. Grillparzer himself must have been aware of the quality of his own heroine when at the outset of the story he sends his narrator on a search amongst the people whom he designates "die Obskuren"11 for traces of the traditional heroines of tragic literature: the Juliets, the Didos, and the Medeas. At the end of the story the object of the search has been found - in the figure of Barbara, who, like her tragic forebears, is thwarted in love.

Barbara is certainly one of "die Obskuren", not only in the sense that she belongs to the lower classes and is obscured by the anonymity of her low social standing, but also in the sense that her real nature is so often obscured in the course of the story. She is obscured firstly by the limited perspective of the two men who narrate her story (Jakob and the unnamed narrator), secondly by the reports of Jakob's colleagues and the opinions of her own father (whose are likewise male perspectives), and thirdly by her own self which in many ways is her own worst enemy. In the light of this continual and many-sided obscuring of Barbara, it is no wonder that she has received such scant attention from critics whether they be English- or German-speaking!

The psychological complexity of Jakob's character has been commented on Spielmann", in Bernd, op. cit., pp. 47-65. Quote p. 64.

8. Heinz Politzer, Franz Grillparzers "Der arme Spielmann", p. 59. Stuttgart 1967.

9. Ursula Mahlendorf, "The Poor Fiddler: The Terror of Rejection", in Bernd, op. cit., pp. 111-132. Quote p. 122.

10. See also Rosemarie Hunter-Lougheed, "Das Thema der Liebe im Armen Spielmann", (in Bernd, op. cit., pp. 79-92), who, in speaking of "Der tiefe Schmerz der um ihre einzige wahre Liebe trauernden Frau" (ibid, p. 92) is one of the few critics to appreciate the depth and extent of Barbara's feelings.

11. GW III, p. 148. 
very frequently, as has more recently that of the narrator. Barbara's, though, is an equally complex nature and it is not only misleading to relegate her to a secondary role in the story but also dangerous to underestimate this complexity by summing her character up too readily and superficially..$^{12}$

The question posed in the title of this paper "The invisible woman?" may seem paradoxical. After all, Barbara appears, at least on the surface, to be a very visible character. Her physical features are introduced at an early stage in the story. She is described in the following terms:

Das Mädchen galt bei meinen Kameraden nicht für schön. Sie fanden sie zu klein, wußten die Farbe ihrer Haare nicht zu bestimmen. $\mathrm{Da \beta}$ sie Katzenaugen habe, bestritten einige, Pockengruben aber gaben alle zu. Nur von ihrem stämmigen Wuchs sprachen alle mit Beifall, schalten sie aber grob und einer wußte viel von einer Ohrfeige zu erzählen, deren Spuren er noch acht Tage nachher gefühlt haben wollte. ${ }^{13}$

Paradoxically, the context in which this first description of Barbara, and especially of her visual appearance, is given illustrates the process of "obscuring" mentioned earlier. This is, as the text makes clear, not Jakob's own description of her, but that of his colleagues. This is in fact Barbara's public reputation on display! Significantly Jakob neither concurs nor disagrees with his colleagues' assessment of her - perhaps because he has no basis on which to make a personal judgement, on account of his relative ignorance of the opposite sex (his mother died some unspecified time earlier and he has no sisters). Jakob's silence here about his own evaluation of Barbara is also typical of his self-effacing unconfident manner. Not only that but his personal impression of Barbara has for the previous two pages been obscured by his preoccupation with describing and playing the song he first hears her singing and then with his own idiosyncratic evaluation of the art of music. Barbara herself has been seemingly forgotten in the course of this description and evaluation, and reduced in the text to the status of a somewhat uncomplimentary parenthesis, "- es war eine Weibsperson, die sang -"14. When at last the singer's identity has been established, her character is summed up in an

12. Such a note of warning has been sounded by Rosemarie Hunter-Lougheed when she speaks of the dangers of "eine Simplifizierung und Verharmlosung [...], die bei einer psychologisch so problematischen Gestalt wie dem Hofratssohn Jakob ebensowenig angebracht sind wie bei der Grieslertochter Barbara" (op. cit. pp. 7980). Hunter-Lougheed gives an illuminating account of the relationship between Jakob and Barbara and rightly stresses the genuine love between them, but she overlooks many of the subtleties and complexities of Barbara's inner nature.

13. $G W$ III, p. 164.

14. Ibid., p. 162. 
even more degrading parenthesis interrupting Jakob's narration, though this time a whole paragraph - the one cited above - is devoted to her description. This description appears more to obscure her than to shed light on her, by striking a note of both negativity and uncertainty in its listing of Barbara's characteristics. She is not considered to be beautiful, she is too small - how small is not stated, has hair of an indeterminate colour (i.e. mousy?); that she possesses "cat's eyes" is a source of debate. It is presumably not the colour that is being alluded to, since later we learn that her eyes are normally grey. Is it then the shape of her eyes? Like almonds? Or is it their expression being referred to here? The latter is more probable - given the sullen and glaring looks that she subsequently directs towards Jakob. The one certain quality that is established about her - apart from her obvious pockmarks (another negative feature) - is her figure. (The use of the word "figure" in the title of this paper was intentionally ambiguous.) Barbara has not the typical 20th century ideal woman's figure such as graces the pages of contemporary popular magazines; hers is a more traditional Eastern European form: short, sturdy, and muscular. She seems to be designed for physical work more than for the aesthetic pleasure of others. Nevertheless, Jakob's colleagues do find in this figure of hers a feature that attracts them. The implication of the next few lines is that she is often having to defend herself against the physical attentions of Jakob's workmates, and this she does very effectively. Her physical attributes are not only made visible here, they are also made very tangible. Jakob himself will later experience at first hand her physical strength.

Such is Barbara as we first see her. The finely tuned reader will notice here that there is more to Barbara than meets the eye. Especially noteworthy is her defensiveness which paradoxically expresses itself in acts of aggressive violence, particularly when she feels that others are invading her personal space in order to harass her physically. Beneath the brusque exterior there is an area of vulnerability.

While we are discussing Barbara's physical features, it is also worth commenting on her age. Early in the story she is referred to simply as a "Mädchen" or as "Jungfer", no specific age being given or even suggested by Jakob in the course of his narration. Only much later, after Jakob's death, does the narrator, having at last seen Barbara in person (whereby he himself ascertains that "es schien fast, als ob sie nie schön gewesen sein konnte"15), come to hazard an estimation of her age - "über die Hälfte des Lebens hinaus". ${ }^{16}$ Once again this is by no means a precise assessment. Not only that but there also seems to be a discrepancy here in the relative ages of Barbara and Jakob. The latter has been referred to as "der Alte" and more specifically by the narrator on their first

15. Ibid., p. 185.

16. Ibid., p. 185. 
encounter as "ein alter, leicht siebzigjähriger Mann"17. We have not been led to believe that there is any vast difference in age between the two protagonists, in fact we suppose that they are approximately the same age. Yet if we assume from this textual evidence that by the time of Jakob's death he is over seventy and she is maybe forty, and certainly not more than fifty, then he appears to have been at least twenty, perhaps thirty, years older than her. But this must be an impossibility, given the fact that Barbara and Jakob are both only beginning their adulthood at the moment when they first meet. Either Grillparzer, like Homer, nodded in this regard, or Jakob has aged considerably beyond his years when the narrator first encounters him and the former merely seems to be in his seventies, while in reality he is much younger.

This question of age is perhaps a lesser consideration here. More important in this context of the narrator's assessment of the aging Barbara is his confirmation of traits in her that Jakob has already conveyed to him: her increase in weight (the ironical play on the ambiguity of the word "stark" - meaning both strong and stout - is a feature of the text), her apparent lack of beauty, her preoccupation with keeping order, her abrupt and often violent gestures, her habit of keeping her head lowered and her eyes averted. This is the figure of Barbara that we have become familiar with through Jacob's own descriptions of her.

However, there is much more to her nature than this rather unprepossessing and in many ways dissatisfying first physical impression and it becomes clear, as one observes her character in the course of the story, that there are other negative traits that frequently come to the fore. The more obvious of these are associated with her aggressive manner: she uses her voice to blame, chide, and scold; she constantly disapproves and criticises; her words are hard, mocking, sarcastic. And her non-verbal communication is equally offputting: her eyes on the few occasions when Jakob catches sight of them are too often indifferent, ice-cold, and arrogant. On the occassion when Jakob approaches her in his attempt to gain the notes of the song he wants so badly, she stands erect in front of him "wobei sie mich mit heftigen Augen anblitzte", ${ }^{18}$ which reminds one of the "Katzenaugen" mentioned earlier. Her gestures too tend to be abrupt and violent ones, not only in the obvious instance of her slapping Jakob on the cheek when he tries to embrace her but also in the small everyday movements of her hands in her father's shop, e.g. when she snatches objects out of Jakob's own hands or constantly sorts and puts things in order. It is no wonder that Jakob has such difficulty in his approaches to her and in trying to fathom her behaviour. She seems to be what the etymology of her name from the Greek suggests: Barbara, the barbarian, one who is uncivilized and uncouth. Even her own father concurs with the view of Jakob's colleagues and sums her up as follows:
17. Ibid., p. 149.
18. Ibid, p. 165. 
Singt eine gute Stimme, hat auch sonst ihre Qualitäten, aber das Feine, lieber Gott, wo soll's herkommen? wobei er Daumen und Zeigefinger der rechten Hand wiederholt übereinanderschob $[. . .]^{19}$

This lack of refinement is evidently seen by Barbara's father as a handicap to her in the marriage stakes. Without the necessary refinement and feminine graces how will she attract a suitable husband with the money to support her (and her father in his old age)? Another possible implication of this gesture is that only the possession of wealth could provide her with such refinement.

Barbara's name though reveals another aspect of her. Not only can she be barbarous in her treatment of Jakob but she is also a barbarian in the original Greek sense of the word: a stranger, a foreigner. This is exactly what she is so much of the time to Jakob. He is constantly baffled by her behaviour towards him. His despairing words after the "happiest day of his life" when he succeeds in kissing her through the glass partition: "Ich wußte nicht recht, wie ich im Sinne des Mädchens stand"20, and then later on losing his inheritance and all possibility of marrying Barbara: "Den Alten [i.e. her father], eigennützig wie er war, begriff ich ganz wohl, aber das Mädchen"2l clearly underline his total bewilderment.

It is another of the paradoxical ironies of the story that the reader comes to know the character of Jakob very well, yet Jakob is named only once in the story when Barbara comes to bid him farewell before she marries the butcher (twice if we take her final words "Die Geige gehört unserem Jakob"22 as a reference to the poor fiddler and not to her $\operatorname{son}^{23}$ ). Even the narrator, who never names himself in the course of his narration, reveals his character, often unwittingly but quite clearly, to his readers. Barbara, though, is named throughout, and frequently, and yet she is the one character whose true nature often appears to the reader to be as much of an enigma as it was to Jakob.

The moment when a character is identified and named is often a significant one in the works of Grillparzer ${ }^{24}$. We have seen how the revelation of Jakob's

19. Ibid, p. 170.

20. Ibid, p. 176.

21. Ibid, p. 180.

22. Ibid, p. 186.

23. Giving her son the name Jakob is of course another indication of the emotional significance that the fiddler has for her.

24. There are many examples one could cite. An apposite example is the moment in the first act of Medea when Kreon's daughter, Kreusa, in speaking of the rumours spread about Medea, is interrupted by the latter identifying herself by name: 
name is left, ironically once again, to the scene of parting between him and Barbara. Her name is likewise introduced at a significant moment: precisely when Jakob himself reveals his own identity - as the son of the "Hofrat" - to Barbara and her father. The latter cannot contain his sudden change in attitude to Jakob and recovering from his initial shock he calls his daughter by name to vacate her chair for his previously unwelcome guest. ${ }^{25}$ Barbara's reaction though is an unwilling one: she shifts on her chair but not from it, and her father must clear a space on his own chair for Jakob. She evidently does not share in her father's hypocrisy or in his desire to flatter. A few seconds earlier though there is a brief moment when Barbara is described, as Jakob watches her for a glimpse of response to his revelation:

Das Mädchen blieb in ihrer Gleichgültigkeit und gebückten Stellung, nur daß sie sich die losgelassenen Haare, fortarbeitend, hinter die Ohren zurückstrich. ${ }^{26}$

Few critics have noted this brief delicate moment. Walter Silz was certainly the first to do so and he comments:

How subtle a touch is her little feminine movement in smoothing the hair over her ears as she hears of Jakob's family connections $[\ldots]^{27}$

Silz at this point goes no further, merely contrasting this response with her father's comical reaction, though he later correctly states that "under her gruff exterior, Barbara possesses a femininity and tenderness that are the more touching because they are rarely displayed" 28 . He also notes that the story is "instinct with vivifying movement and gesture" 29 .

At this juncture the course of our argument changes. Up until this moment when we considered a fleeting and seemingly uncharacteristic gesture of Barbara's, we have been concentrating on the more obvious and off-putting of her habits and mannerisms (both verbal and non-verbal), because these are what others have noticed before us. Similarly, the importance of gesture in Grillparzer's works has been highlighted time and again by commentator ${ }^{30}$, and Der arme Spielmann is

KREUSA [...] Wie hieß sie - Ein Barbarenname wars -

MEDEA mit ihren Kindern vortretend. Medea.

Ich bins!

25. GW III, p. 169.

(GW L p. 903)

26. Ibid, p. 169.

27. Silz, p. 71.

28. Ibid, p. 77.

29. Ibid, p. 71. 
no exception, as Silz indicates. What impresses the reader is not only the emphasis on these fleeting gestures and movements of the human body especially those of Jakob and Barbara - but also the fact that Jakob, who is recounting events that must have happened many years earlier, has such a good talent for recollecting Barbara's gestures and postures in detail. Sadly his tragedy is that he has so little talent for interpreting them. They occur so few and far between, and are interspersed with so many other apparently more obvious responses that because of this, and because of his inexperience with women, he can perhaps be excused his failing.

The second half of this paper is devoted to a closer examination of those few but crucial scenes where something else, something more subtle, hidden within Barbara's nature, comes to the surface and is made visible, even if only very briefly.

Though Jakob seems so ill-attuned to these visible nuances of Barbara's behaviour, there is however one aspect of her - a strikingly non-visible one - to which he is extraordinarily well-attuned, viz. her singing. It is when she is singing that he hears something in her that no-one else seems to hear. What he hears is, in my opinion, no illusion. Whatever the song may come to mean to him later in his life, at the moment when he first discovers Barbara by overhearing her singing, he is responding to a reality, and one that corresponds closely to his own. This reality is an emotional one, a deep-seated emotional need for love and sympathy. ${ }^{31}$

The scene in which contact between Jakob and Barbara is first established is the one where he hears her singing for the first time. The fact that Barbara herself, as the source of the song, is so comprehensively obscured should not surprise us. After all, Jakob is narrating his life story from the vantage point of the present and in this present Barbara is effectively lost to him. He has left to him now only the song as a token of her, and it has become all-important to him. It - along with the rest of his music - has now taken emotional precedence over her in his life. ${ }^{32}$

30. See esp. Joachim Kaiser, Grillparzers dramatischer Stil. Munich 1961.

31. Cf. John Francis Fetzer, who in his article "Jakob: Guardian of the Musical Threshold" (in Bernd, op. cit., pp. 254-272) notes the similarity between Jakob's tears here when he first plays the song for the narrator and Barbara's own tears later at the very end of the story: "The parallel phraseology may be merely a coincidence, or it could be a subtle device on the part of the author to encourage us to read 'between the lines' so to speak, to discover through textual variation of a theme the existence of a reciprocal emotion which is so difficult for both of them to express in the spoken idiom" (pp. 262-3). The latter alternative is in my opinion the correct one.

32. The narrator's lukewarm assessment of the song that Jakob plays also obscures its original significance: "Er spielte, und zwar diesmal mit richtigem Ausdrucke, die 
Nevertheless, in the course of his narration, her presence makes itself increasingly felt. After he has finished his long panegyric to music, he describes Barbara in her physical location crossing the courtyard below. Then she disappears from sight into the bakery where she puts the unbaked cakes into the oven. As she bends down and rises again, the sound of her voice singing conveys the movement of her body up and down in front of the oven. Then she comes out into sight once more and Jakob promptly recognises her as one whom he already knows from his daily grind in the chancellery. But Jakob shares more with her than this brief acquaintance. Though he does not know it at this time, his and Barbara's family situations are, despite their difference in social status, similar to the extent that they are both children of families in which there is no longer a mother. Their family circles lack the warmth of another woman's presence, are deprived of feminine affection and sympathy. It is not unreasonable to assume that they both deeply, and probably unconsciously, miss this maternal love..$^{33}$

The next scene of interest is the one in which Jakob approaches Barbara in the hope of obtaining in notated form the song she sings. As a mollifying gift he brings her the handful of paper he promised her and she accepts it with a slight nod of her head. Then he reveals that he has recently overheard her singing and her reaction to this revelation merits comment: "Sie? Mich? Lieder? fuhr sie auf, und wo?"34. This is clearly the sudden response of someone on the defensive, someone who feels that their privacy has been invaded. There is a brief moment when Barbara is caught off guard, off balance, and feels vulnerable. She immediately rights the balance though by putting Jakob in his proper place: "Wären Sie etwa gar derselbe [...] der so kratzt auf der Geige?"35. This is the Barbara we are more familiar with! Jakob persists in his overtures though and is eventually rewarded with the song he has come to claim. This, we now learn, is evidently Barbara's favourite song, as according to Jakob she sings it most often, and she immediately recognises it from Jakob's description: "Steigt gleich anfangs in die Höhe, kehrt dann in sein Inwendiges zurück und hört ganz leise auf" ${ }^{16}$. Once again the reader is given a very unsatisfactory description - merely the

Melodie eines gemütlichen, übrigens gar nicht ausgezeichneten Liedes [...]" (GW III, p. 162).

33. Jakob's only reference to the loss of his mother is significantly relegated to another brief parenthesis: "- die Mutter lebte seit lange nicht mehr -" (GW III, p. 161).

34. Ibid., p. 165.

35. Ibid, p. 165.

36. Ibid, p. 166. The use of the term "Inwendiges" - unusual in this musical context points by association to the inner realm of Barbara's hidden self to which Jakob seems so well-attuned. 
movement of the melody at first upwards and then back down to its starting point. But for Barbara it is enough, and she adopts her characteristic posture of putting one leg on a stool and begins to sing "mit ganz leiser und doch klarer Stimme das Lied, wobei sie das Haupt duckte, so schön, so lieblich [...]"37. Again we notice that downward movement of the head. Jakob is moved by the beauty of what he hears - and sees? The parenthesis ("so schön, so lieblich") is ambiguous. Does it refer to the beauty of her singing, or of the way she looks, or of both? Jakob then tries to seize Barbara's hand in order to kiss it in gratitude, but she hastily and defensively withdraws it out of his reach. Again she has interpreted his gesture as an unwarranted intrusion of her own personal space, and her swift response indicates that she is used to dealing with men's unwelcome advances, though on this occasion she has misinterpreted Jakob's honourable intentions.

Their next meeting takes place when Jakob comes to collect the notated version of Barbara's song. Barbara identifes him to her father as "ein Herr aus der Kanzlei" 38 at which point she throws away a worm-eaten pea from her assortment of legumes, as if indicating that Jakob should be treated similarly. Then, immediately afterwards, when Jakob identifies himself more precisely as the son of the "Hofrat", there occurs that gesture that we have already mentioned, when she strokes the locks of hair behind her ear. The significance of the gesture is hard to determine in this context. Is it an unconscious one, an instinctive unthinking one of rearranging her loosened hair? Or is it an attempt to make sure that she can hear clearly what Jakob has to say? Or is it a self-conscious gesture of grooming, performed by a woman who knows that she is being watched by a man? If it is the latter, then Silz may be right in describing it as a "subtle feminine movement". The dramatic scene following this one provides a connection here and perhaps an explanation.

Jakob, after the death of his father, goes once again to the grocer's shop in search of sympathy and understanding. Now that he has inherited his father's estate and is planning his future investment, he is accepted willingly by Barbara's father, who hopes to make a "killing" here. Barbara's attitude to him though remains puzzlingly cold and indifferent. Then one day he comes across her with her back turned to him and singing her song - or rather his song, so he believes. She evidently considers herself to be alone and unobserved:

Und dabei sang sie leise in sich hinein. - Es war das Lied, mein Lied! - Sie aber zwitscherte wie eine Grasmücke, die am Bache das Hälslein wäscht und das Köpfchen herumwirft und die Federn sträubt und wieder glättet mit dem Schnäblein. Mir war es, als ginge ich auf grünen Wiesen. Ich schlich näher und näher und war schon so nahe, daß das Lied nicht mehr von außen, daß es aus mir herauszutönen

37. Ibid, p. 166.

38. Ibid, p. 169. 
schien, ein Gesang der Seelen. ${ }^{39}$

This is one of the few truly delightful moments in the story and one which has often been overlooked by critics. What immediately follows it should not obscure the beauty of this moment in our minds. The use of diminutives and the unexpected introduction of nature imagery into a story that is so exclusively concerned with images of life in the city combine to convey Jakob's sense of wonder and ecstasy at the sight and sound of Barbara singing. The most striking image is that of the warbler turning and tossing its head as it preens itself. Here is the connection with those earlier scenes where Barbara likewise was heard or seen to raise and lower her head as she sang; and of course the image of preening reminds us of that brief moment of self-grooming that Barbara performed on her hair earlier. It is in such moments as these that Barbara becomes a different person from the one that is so glaringly obvious most of the time. A previously unseen delicacy and beauty, and an unselfconscious delight in this beauty, transform her almost unrecognisably. This is the Barbara that Jakob recognises and responds so readily to. As she sings, it seems to him as if her song were not just her song but his also. It issues from both their souls. To suggest here that Jakob is hearing merely what he wants to hear, a self-created illusion, is to miss an important point. What he hears and sees is Barbara when she is alone and enjoying her own company, no longer on the defensive, no longer struggling to order the world around her: simply a young woman forgetting her everyday cares, almost totally self-absorbed, and enjoying herself and her ability to express herself in song - her private inner self, one that is susceptible to the experience of joy, pain, and longing. Of course, when she discovers from the hands around her waist that she is not alone and is being manhandled, her reaction is an instinctive one - she lashes out at the invader of her privacy, then immediately regrets her overhasty action and tries to soothe the pain with first a caress and then a kiss. This in turn provokes the ecstatic Jakob, who has for so long been deprived of any human touch and affection. (Even the thunderous slap on his face conjures up heavenly visions in his stunned brain.) This day, one must remember, is for Jakob, "der Glückstag meines Lebens"40. His ardour stirred, he plunges after her, only to be halted by the glass door that she has closed on him. All he can do now is to kiss her through the glass pane that separates them. This pathetic and comic action has been read as a sign of Jakob's insufficiency as a man, of his inability to initiate any real and meaningful contact with the opposite sex. Silz for example goes so far as to suggest that the situation calls for him to break the glass "which was doubtless what Barbara wanted him to do"41 in order to reach her! This is highly

39. Ibid, p. 175.

40. Ibid, p. 176. 
doubtful, as it would probably have resulted in a nasty injury either to himself or to Barbara on the other side of the door! Whatever this scene may say about Jakob though, it also says much about Barbara. She has shown herself capable of both sympathy and affection, and of expressing these feelings towards Jakob. What she finds so hard to accept is Jakob's desire to return these feelings - one might say: with interest! Having exposed her capacity for feeling, she evidently feels vulnerable and instinctively retreats from the advances she has provoked. Her natural strength enables her to resist Jakob's attempts to force open the door. The scene is interrupted at this point by the appearance of Barbara's father who by now has the prospect of a wedding firmly in mind.

The next scene is perhaps the most revealing one with respect to Barbara's character. Though Jakob seems especially obtuse about her intentions in this episode, the hidden side of Barbara is made clearly visible here. It must be assumed that Jakob has succeeded in inducing her to break down some of the inner barriers that she had earlier so steadfastly erected between them. Barbara now seems different to Jakob when he sees her on this next occasion: "[...] sie war gut. Demütig und still, nicht auffahrend wie sonst, $[. . .]^{\text {"42 }}$. She even allows Jakob to sit beside her and help her with her work. Then suddenly she inadvertently scratches herself - how, is not clear, but the act is an appropriate image of her vulnerability. ${ }^{43}$ Her gestures though are revealing: "obgleich sonst gar nicht weichlich, schlenkerte sie mit der Hand hin und her. Ich wollte zusehen, aber sie bedeutete mich, fortzufahren." 44 This is not a typical 19th century heroine who deliberately inflicts a minor injury on herself in order to elicit attention from a sympathetic male, though Barbara's father incorrectly assumes such a ploy on her part here. Jakob in turn shows genuine concern and in return receives none. Instead she gestures to him to move away. It seems to be an instinctive reaction of Barbara's to reject any sympathy shown to her by others. Why she does so, is explained by what follows. Left alone with Jakob, Barbara begins her first honest and open overture to her admirer. In pointing out Jakob's weakness to him, she acknowledges that he needs to have someone at his side whom he can trust:

Sie müssen jemand an der Seite haben, der es ehrlich meint. - Ich wies auf sie. Ehrlich bin ich, sagte sie. Dabei legte sie die Hand auf die Brust, und ihre Augen,

41. Silz, p. 74.

42. GW III, p. 176.

43. Cf. Helmut Bachmaier who comments on this scene (Franz Grillparzer. Der arme Spielmann. Erläuterungen und Dokumente, Stuttgart 1968, p. 78): "Sie ist verletzlich trotz ihrer Stärke und Bestimmtheit; dieser Zug ergänzt ihr bisher feststehendes Charakterbild, das vorwiegend auf Derbheit und Unempfindlichkeit schließen ließ."

44. GW III, p. 176. 
die sonst ins Graulichte spielten, glänzten hellblau, himmelblau. ${ }^{45}$

This is an extraordinary episode. Now, for the first time, we see into Barbara's eyes. We see, as Jakob sees, their colour and the way they change colour on this occasion - not because of some arbitrary play of light but because presumably she is transformed under the emotional impact of the confession and proposal she is about to make. And when a few moments later she reveals her innermost wish for a job which does not involve service - "denn dienen mag ich nicht" - her features change again so that she comes to look like a queen: "Und dabei sah sie aus wie eine Königin"46. To Jakob she has shown a beauty and nobility that he has not seen before, and it would be churlish of the reader to claim that this beauty and nobility were not there, were instead mere subjective illusion on Jakob's part. There is an inner radiance to Barbara's nature that Jakob, and, so it would seem, Jakob alone is privileged to witness. Then Barbara makes her hidden wish known, viz. her desire to own and run the milliner's shop which is for sale next door. To state as Bachmaier does: "Barbara will Putzmacherin (Hutmacherin) werden, ein damals typischer Beruf für Mädchen der unteren Stände"47, is to make a generalisation that obscures a particular and significant point here. It should come as a surprise to us that this so down-to-earth, outspoken, rude and at times violent grocer's daughter who has made her living up till now by working with the basic stuff of life, food, should harbour a secret wish to change career, become a milliner, and deal with such fancy goods and feminine things as silks, ribbons, bows, buttons, and hats. All the more extraordinary this is in the light of her sudden change of tone and the devastating words that then issue from her lips to complete her proposition: "Aber ändern müßten Sie sich! Ich hasse die weibischen Männer". ${ }^{48}$

These words have always been interpreted by critics as a justified criticism of Jakob and his inherent weakness. Some commentaries have pointed out that, while it is true that Jakob has effeminate features, it is also equally true that Barbara has a strong streak of mannishness in her to complement his effeminacy. ${ }^{49}$. What does not as yet seem to have been noticed though is that

45. Ibid, p. 177.

46. Ibid, p. 177.

47. Op. cit., p. 79.

48. $G W$ III, p. 177 .

49. E.g. Browning (op. cit., p. 62): "Masculine and feminine are curiously reversed in this story, Jakob representing the feminine pole and Barbara, whose 'mannish' traits have often been noted, the masculine." See also Bernhard Seuffert ("Grillparzers Spielmann", in: Festschrift für August Sauer. pp. 291-331, Stuttgart 1925) whose comments are quoted by Bachmaier (op. cit., p. 62): "Er ist 
Barbara's words unwittingly say a great deal about herself. The question must be asked: why does she hate effeminate men so? A likely answer is: because she regards all signs of what she thinks of as effeminacy, i.e. those traits especially characteristic of Jakob: sensitivity, courtesy and concern for others, emotional susceptibility, and a need for sympathy, as weaknesses of character. And she is right, to the extent that these are the traits that others can exploit to their own advantage. Barbara, we know, has had to learn life's hard lessons, and is very much concerned with protecting herself from the selfish advances of others. She has built up her defences soundly and surely. However, the above-mentioned characteristics need not merely be weaknesses. Without such sensitivity, without a capacity for allowing ourselves to feel emotions, without a need for close contact with others, we are hardly human. Barbara, too, is human. The features that she has seen Jakob display as his main features are also there within her. Even if they have been reduced and suppressed by her, they still make their presence felt and the keen-eyed reader will not overlook them. Her professed hatred of effeminate men such as Jakob is a sign of her mistrust of her own self. That Jakob should seem such an uncomprehending ninny in her presence is not entirely his fault. Even when she does confront him forthrightly and declares her intentions, she obscures her real feelings by choosing words that constantly seem to stress her commercial interests rather than her emotional ones, so that Jakob misinterprets her use of the word "Antrag"50 to mean a commercial proposition rather than a proposal of marriage. The tragedy is that when she does in this scene show signs of dismantling her protective shell, it is too late: Jakob in his alltrusting innocence has already unwittingly given away his inheritance and from now on is condemned to the life of a poor street musician. Barbara must now go to rejoin those she had wanted so much to escape from: "Ich muß nun hinaus unter die groben Leute, wogegen ich mich so lange gesträubt habe"51. This also is a revelation. The use of the word "grob" here in this context gives the lie to those office-colleagues of Jakob who earlier had summed up her character too simplistically in using the same term. We see her enduring inner resistance, of which there were so few overt signs, and the continual struggle she has made in order not to give in to the soul-destroying restrictions of her social class. The more usual gestures and movements of her body referred to earlier - the abrupt and often violent ones of snatching, slapping, clasping her hands together, sorting and ordering, stamping her foot - suggest an unconscious expression (what behaviourists would call "leakage") of an inner nervous and emotional tension.

zart, sie ist stämmig, er ist höflich, sie ist grob, er ist an Abhängigkeit gewohnt, unterwürfig, sie ist selbständig und herrisch [...] Zweifellos sind die Unterschiede aneinander aufgebaut".

50. GW III, p. 177.

51. Ibid., p. 181. 
Certainly, one aspect of her personal tragedy is that, in this struggle to protect and preserve her self, she has had to use the weapons of the enemy and has made herself seem in many respects as coarse and uncouth as the people she wishes to free herself from. Now the battle that she has fought for so long is lost.

Could it have happened otherwise? What, say, if Jakob had retained his inheritance and were able to take up Barbara's offer? The hypothesis is worth exploring briefly. Might it not be possible that, when Barbara had the security she so desperately needs, she, would be able to teach Jakob how to cope with everyday life, how to, for example, manage the accounts and correspondence in the millinery shop? Might it not also be possible that she would learn from him how to accept and express that side of herself which she had for so long hidden and suppressed? Might it not even be possible that after a successful day's business, the evenings would be spent in music - Jakob with his violin accompanying Barbara as she sings, both learning together to develop what in reality never has the chance to be developed? Might then music not become an experience of sharing? Music not as solitary solipsism but as emotional dialogue and communication? These are all mighty "mights" and must remain what they are pure speculation. The final reality is much crueller, but it is a reality that both Jakob and Barbara must learn to accept.

It is easy to view Barbara's reaction when she learns of Jakob's loss of his inheritance merely as one of disappointment that her chances of bettering herself socially and financially are now gone, but one senses in the intensity of her physical response the corresponding intensity of an emotional state which mere materialistic loss would not have induced:

Ich [...] wendete mich gegen das Mädchen, die, auf den Ladentisch gestützt, dastand, die Augen auf den Boden gerichtet, wobei die Brust heftig auf und nieder ging. Ich wollte mich ihr nähern, aber sie stieß zornig mit dem Fuße auf den Boden, und als ich meine Hand ausstreckte, zuckte sie mit der ihren halb empor, als ob sie mich wieder schlagen wollte. 52

Likewise when she comes to return Jakob's laundry and to bid him farewell before she goes unwillingly to marry the butcher, her reactions are more than those of a woman who has lost her chance of betterment. She is pale, she sighs deeply, finally bursts into tears and is so shaken that she has to sit down:

Es schien fast, als ob ihr schlimm würde, denn sie setzte sich auf einen Stuhl neben dem Schranke, verbarg das Gesicht in ihr Tuch, und ich hörte aus den stoßweise geholten Atemzügen, daß sie noch immer fortweinte. ${ }^{53}$

52. Ibid, p. 179: 
Eventually she regains her composure and makes one final gesture in his direction:

Und nun hob sie die Hand auf, machte wie ein Kreuzeszeichen in die Luft und rief: Gott mit dir, Jakob! - In alle Ewigkeit, Amen! setzte sie leise hinzu und ging. ${ }^{54}$

But even now, there is still one last moment of uncertainty when she must struggle with her emotions:

[Ich] rief [...] ihr nach: Barbara! Ich hörte, daß sie auf der Stiege stehenblieb. Wie ich aber die erste Stufe hinabstieg, sprach sie von unten herauf: Bleiben Sie! und ging die Treppe vollends hinab und zum Tore hinaus ${ }^{55}$.

All these are signs that she is leaving Jakob only with great reluctance and which make it clear that Jakob has stirred feelings within her that she has difficulty controlling and coming to terms with. In the end, she succeeds in suppressing her emotional needs, submits to necessity, and descends the staircase to the outside world. ${ }^{56}$

Jakob seems blissfully unaware of her inner struggle. ${ }^{57}$ In his typically selfeffacing way, he feels relief that Barbara will now be free of material and financial need. He has no inkling of the emotional effect he has had on her, and he dies in this state of ignorance. It is left to the narrator to witness the last poignant scene

53. Ibid, p. 180.

54. Ibid, p. 181.

55. Ibid, p. 181.

56. A small number of critics have noted that Barbara has difficulty in expressing her deepest emotions, a difficulty which contributes to the process of "obscuring" emphasised throughout this paper. E.g. Martin Swales writes "[Barbara] cares for the Spielmann in a way that she will not and cannot express" (in Bernd, op. cit. p. 74). Likewise James I. Porter writes of "Barbara, whose words ('eigentlich verdienen Sie kein Mitleid') cannot ever be taken at face value, so wrongly does her representation of her emotion obscure [!] her actual sentiments, which in the context of the story can be better shown than told" (J. Porter, "Reading Representation in Der arme Spielmann" in Bernd, op. cit., p. 201).

57. Another of Grillparzer's tragic heroines who suffers a similar intensity of inner conflict, a conflict which betrays itself in her gestures, is Erny in Ein treuer Diener seines Herrn. Interestingly, Eny herself is introduced at the moment when a song is being sung, the words of which only she hears and attends to, while her husband Bancbanus notices only the music ( $G W \mathrm{I}$, p. 1090). One can compare the misunderstanding between Barbara and Jakob over the nature of the song she sings (GW III, p. 166). 
which reveals the enduring depth of her feelings for Jakob.

In this final scene Barbara is raised to the heights of those tragic heroines of literature mentioned at the outset: a woman who sees and knows the inevitability and the tragedy of her situation, the denial of her inner self and its secret wishes. The simple act of taking Jakob's violin down from the wall and shutting it away in a drawer brings the full tragedy of her situation home to her. She recognises now the importance of what had come to matter most to Jakob, his music, embodied in his violin, but in the absence of Jakob's person she cannot realize, in the sense of make real in herself, that side of Jakob which attracted her to him in the first place. She treats this part of Jakob as though it were merely part of the rest of her world, i.e. as a material possession. Her involuntary gesture is one of repossession, of laying claim to something that, as she herself realizes, cannot be repossessed. She grasps in the end the positive significance of the kind of inner life represented by Jakob's music which she, in her over-defensive manner, has cut herself off from.

Even here, at the very end, the last image of Barbara with tears streaming down her cheeks is "obscured" to some extent. The narrator describes but does not interpret. Some sense of the intensity of Barbara's emotion is conveyed in the phrase "stromweise" 58 but that is all. The reader is left wondering whether the narrator has in fact lived up to the claim he made at the outset of his story: "[...] man kann die Berühmten nicht verstehen, wenn man die Obskuren nicht durchgefühlt hat." 59 - From his final silence we do not know the extent of his empathy. Or even his sympathy. Or is it embarrassment? Or even indifference? The interpretation of Barbara's tears is left for us to make. In the light of what we now know of Barbara, of both her visible and her hidden nature, we recognise that this is grief - silent, wordless grief - not only for the death of Jakob but also for the death of a part of herself, her most secret, inward, and vulnerable self that only the poor musician had found access to, that only he could have released.

58. GW III, p. 186.

59. Ibid., p. 148. 